\title{
Aceh Traditional Clothes In The Current Globalization Of The World
}

\author{
Mukhirah \\ \{mukhirah.fkip@gmail.com\} \\ Department of Vocational and Social Welfare, Faculty of Teacher Training and Education, Syiah Kuala \\ University, Darussalam 2311, Banda Aceh, Indonesia
}

\begin{abstract}
Traditional Acehnese clothes are part of the regional cultural arts products that have high aesthetic values, so that their existence needs to be maintained as a cultural asset from the ancestors. Aceh Province as the gateway to the archipelago had a lot of cultural contact and outside influence. So that the influence is also colouring traditional Acehnese clothes that is developing. The element of Islamic values is the main benchmark in the creation of traditional Acehnese clothes. Therefore, various unstoppable outside influences at this time should not damage the existing values of traditional Aceh clothes. The purpose of writing this paper is intended as a refresher material for the people of Aceh, especially to appreciate the cultural work of the previous generation, and other parties who want to know about the ins and outs of traditional Acehnese clothes. The phenomenon that occurs today is often the traditional Acehnese bride's clothes have deviated from the peculiar characteristics, both those used at weddings, and wedding parties. The rapid pace of globalization of the world is so fast, little by little it has damaged the order of traditional cultural arts in dressing among the people of Aceh. As an element of cultural arts, traditional Acehnese clothes can be developed in accordance with the times, but the elements that become distinctive need to be maintained and preserved.
\end{abstract}

Keywords: Traditional Clothes, Current Globalization, Aceh

\section{Introduction}

Acehnese cultural arts are full of Islamic values which are the ancestral heritage of the past. Therefore it is necessary to preserve and develop custom and culture as one of the tourism potentials through strengthening, understanding for the implementation of the Dinul Islam and cultural arts in a unity with religion as its principle In the writings of [1] it was explained that in its graphic position the Aceh region as the gateway to the archipelago made Aceh a lot of cultural contact and outside influence. One of them is the influence of Islamic religion which was first spread and adapted to elements in the Persian and Gujarat or Indian regions. This can be seen in the socio-cultural life with the influence of Islamic religion which is so strong which causes the mindset, attitudes and behaviour of the Acehnese people in their daily lives to be adjusted to Islamic rules. Traditional Acehnese clothes are part of the regional art and culture products that have become the pride of the Acehnese people, and are even 
admired by other nations in the world. Traditional Acehnese clothes have a very high aesthetic value, so the clothes are often the centre of public attention in every exhibition and regional cultural arts both at the national and international levels. Acehnese traditional clothes have differences between Aceh in coastal areas and rural Aceh. Coastal Aceh includes: Aceh Besar, North Aceh, East Aceh, West Aceh, South Aceh and Pidie.

The six districts located on the coast have similarities in the shape and model of their clothes, but there is little difference in the embroideries used. Aceh Besar Regency as one of the areas that is still strong_with the contents of the elements of its traditional culture which is still faithful in upholding traditional traditions used in every traditional ceremony. The peculiarities of traditional clothes in Aceh Besar can be seen from the elements of the original shape, colour, decoration and accessories. In the modification of the clothes model that was developed, it was still seen as an element that became the characteristic of the Aceh region.

As one of the products of culture, Aceh Besar traditional clothes are not only a deluge but also needs to be developed, but still maintaining the distinctive elements of the clothes. The aesthetic value of traditional Acehnese clothes remain in line with the rules of Islamic law, because Islam itself does not forbid anything beautiful as long as everything that is used is based on sincere intentions. Allah Subhanahu Wata'ala said which means: "Son of Adam, in fact we have lowered clothes to cover your genital and beautiful clothes for jewellery. And godfearing clothes is the best, that is part of the signs of God's power, hopefully they will always remember ". (Q.S. Al-A'raaf: 26) . Rasulullah Salallahu Alaihi Wasallam also said "Allah is Beautiful and loves beauty" (Narrated by Bukhari).

Based on the words of Allah and the Hadith as mentioned above, it can be understood that beautiful clothes have no restrictions in Islam. Every clothes design by observing the conditions in accordance with the provisions of Islamic law can be developed. Thus the writing of this paper was aimed to preserve and develop Acehnese traditional clothes as regional assets that have aesthetic value, while remaining based on Islamic values in the current globalization of the world.

\section{Discussion}

As other tribal communities in Indonesia, the people of Aceh also develop traditional clothes as a symbol of their identity. One of them is the clothes worn by the groom (linto baro clothes) and the bride (dara baro clothes) at the wedding party ceremony. In the Acehnese society wearing traditional wedding attire for those who hold a wedding party has become a tradition (habit) since the past. Every bride and groom, both male and female, wearing traditional clothes equipped with jewellery of various shapes. Between the traditional clothes of the groom and the bride have their own peculiarities, each of which has its own meaning. For clearer understanding, the following describes the groom's clothes and the bride's clothes.

\subsection{Traditional Clothes of Acehnese Bridegroom}

\subsubsection{Groom's Clothes (Linto Baro)}

The groom wears clothes in the form of a Chinese collared long-sleeved suit and front button (baje kot). In the front part, the pocket and the end of the hand are decorated with embroidered gold thread, bamboo shoots. The buttonhole is embroidered with three-pointed motifs, each of them propagates left and right. As a pair of groom's suits, the pants (sileuweue) are made of the same material, and usually the pants made of cotton or black wool. The 
bottom of the pants was also embroidered with gold thread with a motif that matched the shirt. At the waist of the pants wrapped around a songket sarong called ija krong to a limit of about $10 \mathrm{~cm}$ above the knee. After the clothes and pants and songket clothes worn by the groom, the head cover is cap (meukeutob). This type of head covering was known during the reign of Sultan Iskandar Muda (1607-1636). In the course of the history of this skullcap has also been used by Acehnese hero figures such as Teuku Umar, Teuku Panglima Polem, and head of regions in Aceh [2]. Seen from its shape, meukeutob is similar to a hat which is still used by Kurds in Turkistan, and according to its history the origin of meukeutob indeed originated from that country. According to [3] this fact can be justified because during his reign, Sultan Iskandar Muda once established special cooperative relations with the kingdom of Turkey, both in the trade and culture of the Turkish Empire. The meukeutob skullcap on the top is equipped with an octagonal star shaped pad consisting of three levels. This look is made of gold and silver, or gold plated, and it is decorated with white and red gems. In addition to the look, meukeutob skullcap is also equipped with multilevel tassel (priek-priek). At the level of one another it is connected with a gold chain so that it is in the form of breadfruit leaves.

The jewellery or accessories worn by the groom consist of taloe jeuem, which is a chainshaped ornament and has toys in its end like a two-tailed fish and a key shaped ornament. At both ends of the chain there are eight shaped hooks, and how to wear them is by attaching to the chest part of the dress, besides that there are also boh ru bungkoih ornaments which is a kind of young areca-shaped ornaments, carved in such a way that they are shaped like hanging pillars in $\mathrm{d}$ Traditional Aceh house buildings. The decoration is tied to the clothes (Ija seumedah) which is hooked on the right shoulder.

Dagger (reuncong) is a traditional Acehnese weapon whose shape like L letter. The use of dagger in the groom's traditional attire is tucked in the waist on the left side of the front with the handle facing to the right, precisely between cloth loops. According to [4] that the use of dagger in the Acehnese tradition has its own cultural value that signifies the strength of a man. The last complement of clothes for the groom is black shoes which is matching the clothes and pants.

\subsubsection{Bride's Clothes (Dara Baro)}

For the bride's clothes also consists of shirt (baje)), pants (sileuweue meutunjong) and songket sarong (ija krong) and other jewellery. The bride with a Chinese collared long-sleeved blouse decorated with gold thread embroidery. The colour of the shirt is usually red, yellow and green, made of silk or beled. The motifs on the clothes are usually on the neck and end of the arm. But in the times of the clothes motifs have been added to the chest, arm or pocket and this is called modification. In making these modified clothes [5] stated that the modification was to adjust the mode, namely changing the forms of the motif, but did not leave the traditional characteristics and adapted to the present life.

Pants (seuleuweue meutanjong) in the form of wide pants at the top and shrinking to the tip of the foot embroidered with gold or silver thread. The pants, although small at the end, but it is very polite when it is worn because they do not form the thighs or calves. The pants are usually black or dark purple called sileuweu lambayoung. After these pants are worn on it, it is wrapped in songket cloth (ija krong) which is about below the knee. [6] states that ancient Acehnese fabrics were woven by hand. This traditional method began to be rarely carried out but still exists in some Acehnese villages, such as the Siem village.

Jewellery for brides is more various than jewellery for groom. The types of jewellery used by the bride are: culok ok, patham dhoe, subang bungong mata uroe, taloe taku lhee lapeh, keresang, simplah, taloe keieng, klah taku, gleung jaroe, gleung gaki and encin. Patham Dhoe is one of the jewellery that is placed in a beautiful carved crown. The original patham dhoe 
was made of 24 carat gold decorated with white gems, on the left and right side were decorated with floral and leaf motifs, while the middle part was carved with calligraphy written by Allah and Muhammad. This motif is called the kalung kalimah which is circled in small circles on the edge. If the bride has worn the jewellery, it means that from that moment on, she has been crowned a legitimate wife, regardless of her parents' responsibilities and has officially formed her own household. To complete the Acehnese bride's attire, the last one is the slippers which are usually called selop meukasab, then the Acehnese traditional dress is perfect for the bride.

\subsection{The Influence of Globalization in the Development of Acehnese Traditional Clothes}

The current of globalization in the world has affected various aspects of human life, including the style of using traditional Acehnese clothes. According to Acehnese tradition, traditional clothes are not only worn during wedding ceremonies, but also worn by warlords, welcoming honoured guests, circumcision, and other traditional ceremonies. As one of the regional cultural elements, traditional Acehnese clothes need to be nurtured, preserved and developed, so that the culture remains known by the next generation of the nation.

Due to the unstoppable influence of foreign culture, it has had a positive and negative impact on the development of traditional Acehnese clothes models. The positive impact is that it can enrich the treasures of national culture by recognizing various traditions and external cultures, while the negative impact is the shift in local culture by changing the traditional clothes model by eliminating the distinctiveness of the Aceh region itself. The fading of regional culture is feared to be able to eliminate the joints of Aceh's originality of culture, so that it is no longer known by the younger generation in the future. Acehnese traditional clothes that is rich in various forms and decorations is very influential in increasing the potential of regional tourism. For the next discussion, we will explain the clothes worn in weddings and clothes at wedding parties.

\subsubsection{Clothes in a Wedding Event}

Before carrying out the wedding party a pair of brides first carry out the marriage contract, which is usually held at the bride's house, in the meunasah (small mosque) or in the mosque. Today the marriage contract is rarely done at home, but almost all of them have chosen meunasah (small mosque) or mosques as the sacred event venue. The marriage contract which is a sacred promise in forming a household that is sure to be a warahmah should be reflected in the procedure for dressing bride and groom especially the Aceh region, known as the Veranda of Mecca and Islamic Shari'ah. But what is happening now is really worrying, where there have been many propagated clothing that is inappropriate for Muslims.

We have often seen at weddings at the mosque the bride wore a tight-bodied and longtailed dress sweeping the floor, which cost a relatively large amount. Though these clothes are commonly used by non-Muslims during marriages in the church with the gospel in their hands, their heads are decorated with a tapered upward shape that resembles a camel's hump. Whereas it is strictly prohibited in Islam such as the words of the Prophet Sallallahu Alaihi Wassalam "There are two groups of dweller of hell who I have never seen both, namely 1) you who make a whip like the tail of a cow that they use to beat people (cruel rulers), 2) women who dress but are naked who tend to make immorality and their hair like a hump of a camel with a swing. They will not go to heaven and will not smell heaven, even though the smell of heaven can be smelled from afar "(HR. Bukhari). 


\subsubsection{Clothes in Marriage Events}

In its development, the traditional Acehnese wedding attire that is usually worn at weddings has shifted a lot in terms of shape, colour, and embroidery motifs and jewellery. Today there are many models of traditional bride clothes that have begun to move away from the peculiarities of the Acehnese, thus it removes the symbol of the ancestors' identity.

Changes in the form of clothes can be seen from the form of women's clothes that are originally loose and now has begun to be made to fit tightly. The Aceh pants, known as sileuweu meutunjong, have now turned into pencil pants that are also tight. The colours of Acehnese clothes with certain symbols are not noticed anymore. In addition, the Aceh motif that adorns women's clothes has now been changed like a tight kebaya made from brocade, or plain material that is filled with patches of lace material. A very prominent shift is more directed at women's clothes, and it has often happened at traditional Acehnese wedding parties, worn kebaya and cloth, while the head remains Acehnese jewellery. This clearly has damaged the order of traditional cultural arts in dress, because kebaya clothes as the national clothes of the Indonesian people are combined with head jewellery from traditional Acehnese bridal makeup.When it is seen thoroughly in the makeup of the Acehnese bride that is happening today, not only the change in clothes but also jewellery which no longer has the peculiarities of the region. For example a headdress that is made too high, a and crown and flower hand that is usually used by non-Muslim brides with slowyer clothes (a tight-bodied and long-tailed dress sweeping the floor). Even though the actual Acehnese bridal makeup is not so, so that the shift that occurs little by little will dissolve the original cultural arts of Aceh.

From the two types of clothes, which are worn in weddings and marriages, as the authors describe above, it can be used as a problem solving topic about the phenomenon that occurs at this time. For people who love Aceh culture, of course, they will maintain their culture, one of them is Aceh Besar District which was the focus of the study in this seminar.

\section{Conclusion}

Traditional Acehnese clothes as a cultural aspect re not synonymous with cultural understanding in general, because the joints of the building of custom are derived from Islamic religious values. The spirit of Islam has inspired and revived Acehnese culture, thus expressing to philosophical values which eventually became the ideal cultural foundation. The tradition of dressing in Acehnese society should always be guided by Islamic cultural values by prioritizing the requirements that apply in Islamic law. The traditional wedding attire along with the jewellery when examined deeply, it contains values that guide the life of the community. These values are in the form of historical values, traditional values and traditions, Islamic law values and Islamic values, ethical values and aesthetics. Modifications to traditional Aceh clothes may be developed as long as they do not eliminate the elements which are characteristic of the region. Changes in models, materials, colours and jewellery may be made in such a way in accordance with the demands of the times. 


\section{Suggestions}

1. It is expected that all relevant parties such as the Aceh Customary Assembly (MAA) of the Tourism Office, the Islamic Shari'a Office, can pay attention to the shift in cultural values that occur today in the manner of dress for the Acehnese people.

2. For all the young generation of Aceh, they need to get to know the ins and outs of traditional Acehnese clothes more deeply, so that the love of culture itself is more inherent in the person as a Muslim society.

3. Bridal stylists and dressers should not only deepen knowledge in terms of fashion design and makeup in general, but need to have knowledge of the characteristics of Islamic Acehnese culture.

\section{References}

[1] Nyakpha, Judge, and Sufi, "Customs and Culture of Aceh." Traditional History and Value Study Center, Banda Aceh, 2000.

[2] H. Rasyid, "Covering the Head of Acehnese Ethnic Men," 2000.

[3] F. Zainuddin, People's Resistance to Hegemony of Power. Surakarta: Muhammadiyah University Press. Asia Foundation, 1999.

[4] C. I. E. Arby, Makeup and Traditional Marriage Ceremony of Aceh. Jakarta: Meukuta Alam Foundation., 1989.

[5] R. Sufi, "Customs of the Acehnese Community." Aceh Darussalam Province Culture Service, 2002.

[6] Wood, C. Marlyn, and A. Aprillia, Aceh Bridal Makeup. Jakarta: PT. Gramedia Main Library., 2012. 

